\title{
Afrikkalaisen sikaruton taudinpurkauksen simuloidut taloudelliset vaikutukset Suomessa
}

\author{
Jarkko K. Niemi ${ }^{1)}$, Tapani Lyytikäinen ${ }^{2)}$, Leena Sahlström ${ }^{2)}$, Heikki Lehtonen ${ }^{1)}$, Jonna Kyyrö ${ }^{2)}$ ja Alina \\ Sinisalo ${ }^{1)}$ \\ 1) Luonnonvarakeskus, Latokartanonkaari 9, 00790 Helsinki \\ ${ }^{2)}$ Elintarviketurvallisuusvirasto Evira, Mustialankatu 3, 00790 Helsinki
}

\section{TIIVISTELMÄ}

Afrikkalainen sikarutto on helposti leviävä virustauti, jota ei ole tavattu Suomessa. Tauti voi aiheuttaa mittavia kustannuksia kotieläinalalle ja veronmaksajille, sekä häiritä sioista saatavien tuotteiden kansainvälistä kauppaa.

Afrikkalainen sikarutto on levinnyt viimeisten kahden vuoden aikana Venäjältä Puolaan ja Baltian maihin. Esimerkiksi marraskuuhun 2015 mennessä Virossa oli raportoitu 18 kotisikatapausta ja lähes 500 villisikatapausta. Suomen ja Baltian välillä on vilkas matkailijaliikenne, ja maatilojen välillä on yhteistyötä, joten riski taudin leviämiseksi Suomeen on jatkuvasti olemassa.

Tämän tutkimuksen tavoitteena oli selvittää, millaisia taloudellisia tappioita afrikkalainen sikarutto voisi aiheuttaa Suomeen levitessään. Tutkimusmenetelmänä käytettiin stokastista Monte Carlosimulaatiomallia, joka jäljittelee taudin leviämistä Suomessa sen jälkeen kun tauti on levinnyt yhdelle Suomen sikatiloista, sekä osittaisen tasapainon mallia, joka jäljittelee sikamarkkinoiden tilannetta Suomessa. Simulaatiot tehtiin sekä vuoden 2009 tilarakenteella että vuoteen 2033 sijoittuvina projektioina.

Afrikkalaisen sikaruton simuloitiin aiheuttavan tyypillisesti 10,5 miljoonan euron (95\% välillä 4,622,7 miljoonaa euroa, keskimäärin noin $7400 €$ per sikatila) menetykset suomalaiselle sika-alalle. Verovaroista korvattavien välittömien kustannusten arvioitiin jäävän tyypillisesti alle puoleen miljoonaan ja useimmissa tapauksissa alle miljoonaan euroon. Tulos johtui sitä, että simulaatioiden perusteella taudin arvioitiin leviävän useimmiten vain 1-2 sikatilalle. Tartunnan saaneen tilan koko, tyyppi ja sijainti vaikuttivat tappioihin.

Verovaroista korvattavat kustannukset ovat kuitenkin vain osa kokonaiskustannuksista. Suurimmat taloudelliset tappiot arvioitiin aiheutuvan kotieläinyrityksille (sikatilat, lihateollisuus), joiden menetysten arvioitiin olevan 7,4-38,1 miljoonaa euroa. Taudin esiintyminen Suomessa keskeyttänee sikatuotteiden viennin EU:n ulkopuolisiin maihin, ja jossain määrin myös EU:n alueelle. Siten kotimaan markkinoille syntyy ylitarjontaa, joka laskee sianlihan hintaa Suomessa. Kuluttajien (kuluttajat, kauppa) simuloitiin hyötyvän hetkellisestä ylitarjonnasta 3,1-15,8 milj. euroa. Lisäksi tappioiden suuruuteen vaikuttaa se, miten voimakkaasti ja miten pitkäksi ajaksi sianlihan vienti heikkenee. Tulokset viittaavat siihen, että jokainen lisäkuukausi aiheuttaisi kansantaloudelle 2-3 miljoonan euron lisätappiot. On mahdollista, että rajoitukset kestävät joidenkin vientikohteiden osalta useita kuukausia, jopa vuosia, ja ne voivat koskea koko Suomen sianlihantuotantoa riippumatta siitä, miten laajalle tauti pääsee leviämään.

Afrikkalaisen sikaruton taloudelliset tappiot olivat samaa suuruusluokkaa vuoden 2009 tilanteessa ja vuoteen 2033 sijoittuvissa projektioissa, joskin verovaroista korvattaviin kustannuksiin liittyvä riski nousi nykytilanteeseen verrattuna.

Asiasanat: Afrikkalainen sikarutto, eläintauti, tappiot, vienti 


\section{Johdanto}

Afrikkalainen sikarutto on helposti leviävä sikojen virustauti, jota ei ole tavattu Suomessa. Riski taudin leviämiseksi Suomeen on kuitenkin jatkuvasti olemassa ja sen voidaan arvioida kasvaneen viime vuosina. Afrikkalainen sikarutto on levinnyt viimeisten kahden vuoden aikana Venäjältä Puolaan ja Baltian maihin. Esimerkiksi marraskuuhun 2015 mennessä Virossa oli raportoitu 18 kotisikatapausta ja lähes 500 villisikatapausta (OIE, 2015). Suomen ja Baltian välillä on vilkas matkailijaliikenne, ja suomalaisten ja virolaisten maatilojen välillä on yhteistyötä, joten riski taudin leviämiseksi Suomeen on jatkuvasti olemassa. Tauti voisi levitä Suomeen esimerkiksi Virossa käyvän villisikoja metsästävän matkailijan tai virolaisessa sikalassa käyvän matkailijan mukana (vrt. Oravainen ym. 2011). Tautiin ei ole hoitoa eikä rokotetta ja sen oireita ovat muun muassa sikojen äkillinen kuolleisuus ja korkea kuume.

Afrikkalaista sikaruttoa vastustetaan viranomaisten toimesta (ks. European council 2002, MMMa 2014). Afrikkalaisen sikaruton esiintyminen voi aiheuttaa mittavia kustannuksia kotieläinalalle ja veronmaksajille, sekä häiritä sioista saatavien tuotteiden kansainvälistä kauppaa. Kansainvälisen eläintautijärjestön (OIE, 2007) sekä kansainvälisten kauppasopimusten (WTO) mukaan muilla mailla on oikeus kieltää sikojen ja sioista saatavien tuotteiden tuonti maahansa, mikäli Suomessa havaitaan afrikkalaista sikaruttoa. Esimerkiksi sikojen ja sikaperäisten tuotteiden tuonti niiltä alueilta Baltiassa, jossa tautia on havaittu, on kielletty muualle EU:n alueelle (Euroopan komissio 2015). On mahdollista, että muiden kuin EU-maiden reaktiot voisivat viennin osalta olla huomattavasti voimakkaampia: rajoitukset saattaisivat kestää useita kuukausia, jopa vuosia pidempään kuin OIE suosittelee, ja ne voisivat koskea koko Suomea riippumatta siitä, miten laajalle tauti pääsee leviämään. Esimerkki sianlihan vienti Venäjälle on ollut keskeytyneenä tammikuusta 2014. Rajoitusten perusteena on käytetty afrikkalaisen sikaruton havaitsemista EU:n alueella.

Tämän tutkimuksen tavoitteena oli selvittää, millaisia taloudellisia tappioita afrikkalainen sikarutto voisi aiheuttaa Suomeen levitessään. Tutkimusmenetelmänä käytettiin stokastista Monte Carlosimulaatiomallia, joka jäljittelee taudin leviämistä Suomessa sen jälkeen kun tauti on levinnyt yhdelle suomen sikatiloista, sekä osittaisen tasapainon mallia, joka jäljittelee sikamarkkinoiden toimintaa Suomessa. Simulaatiot tehtiin vuoden 2009 tilarakenteella sekä vuoteen 2033 sijoittuvina projektioina.

\section{Aineisto ja menetelmät}

\section{Epidemiologinen simulaatiomalli}

Afrikkalaisen sikaruton leviämistä sikatilojen välillä arvioitiin Monte Carlo-simulaatiomallilla. Malli tuottaa kussakin iteraatiossa tartunnan saaneiden tilojen lukumäärän, tartuntatilojen tunnistetiedot sekä taudinpurkauksen keston. Mallissa taudin leviäminen oletetaan mahdolliseksi tartuntatilalta lähtevän eläinkuljetuksen, eläinkuljetusajoneuvon tai eläinsuojassa käyvän ihmisen välityksellä.

Malli parametrisoitiin vuoden 2009 tiedoilla ja se kuvaa tilannetta, jossa Suomen sikatuotantoon olisi levinnyt afrikkalainen sikarutto vuonna 2009. Lisäksi simuloitiin taudin leviämistä vuoteen 2033 sijoittuvassa projektiossa, jossa sikatiloja oli vähemmän ja ne olivat kooltaan suurempia kuin vuonna 2009. Taudin ominaisuuksia kuvaavat tunnusluvut perustuvat suurimmalta osaltaan aikaisempiin tutkimuksiin . (Stegeman ym. 2002; Nigsch ym. 2013; Raulo ja Lyytikäinen 2005, ks. myös Lyytikäinen ym. 2015). Mallissa taudin leviämisreitit kuvataan rekisteri- ja kyselytietojen avulla. Eläinkuljetusten osalta verkostokuvaus sisältyy eläinkuljetus- ja tilarekistereihin, jotka kuvaavat eläinsiirtojen tapahtuma-ajat, eläinten alkuperän ja päätymispaikan.

Taudin leviämistä ehkäisevät ja sen hävittämiseen tähtäävät toimenpiteet perustuvat afrikkalaisen sikaruton vastustuksesta säädettyyn lainsäädäntöön (ks. European council 2002, MMMa 2014). Jos Suomessa havaitaan afrikkalaisen sikaruton taudinpurkaus, havaitun tartuntatilan ympärille perustetaan suoja- ja valvontavyöhykkeet, joilla olevat tilat tarkastetaan ja eläinten sekä tiloille menevien ja lähtevien ihmisten liikkumista rajoitetaan taudin leviämisen estämiseksi ja mahdollisten tartuntojen havaitsemiseksi. Tutkimusta varten simuloitiin 100000 erilaista taudinpurkausta, jotka aloitettiin vuoronperään kultakin suomalaiselta sikatilalta. Mallinnustapa on kuvattu yksityiskohtaisemmin Lyytikäisen ym. (2015) raportissa. Tutkimuksessa jäljiteltiin taudin leviämistä Suomessa sen jälkeen, kun tauti on levinnyt yhdelle sikatiloista. 
Leviämistä tutkittiin Monte Carlo-mallilla ja vaikutusta sikamarkkinoihin osittaisen tasapainon mallilla. Analyysit tehtiin vuoden 2009 tilarakenteella. Lisäksi taudin leviämistä arvioitiin tulevaisuudessa, vuonna 2033, jolloin tilat ovat suurempia mutta niiden lukumäärä oli vain viidennes vuoden 2009 tiloista.

\section{Osittaisen tasapainon malli ja taloudelliset menetykset}

Afrikkalaisen sikaruton aiheuttamat taloudelliset menetykset määritettiin kahdessa vaiheessa. Ensin määriteltiin tautipurkauksen vaikutus tiloilla olevien eläinten määrään ja siten tuotantoon sekä laskettiin taudin hävittämisestä aiheutuvat suorat kustannukset. Suorilla kustannuksilla tarkoitettiin verovaroista korvattavia kustannuksia, kuten tartunnan saaneiden eläinten lopetuksen ja hävityksen kustannuksia, tiladesinfektioiden kustannuksia, näytteenotosta, tilojen tarkastuksista ja muusta viranomaisten toiminnasta aiheutuvia suoria kustannuksia. Suorien kustannusten laskennassa hyödynnettiin aiemmin kerättyjä taustatietoja (Lyytikäinen ym. 2010), jotka päivitettiin vastaamaan vuoden 2009 hintatasoa.

Toiseksi tautipurkauksen tuotantovaikutuksia ja kestoa kuvaavia tietoja käytettiin numeerisessa osittaisen tasapainon mallissa tautishokkina (Kuva 1). Mallilla tutkittiin taudinpurkauksen vaikutusta kuluttajien (sis. kauppa) ja tuottajien taloudelliseen ylijäämään. Malli maksimoi sikasektorin tuottaman taloudellisen ylijäämän ja minimoi samalla tautishokista aiheutuvan kustannuksen. Mallin tuottama ratkaisu perustuu stokastisen dynaamisen ohjelmoinnin menetelmään. Osittaisen tasapainon mallilla simuloidaan, miten afrikkalaisen sikaruton esiintyminen Suomessa ja siihen liittyvä ulkomaankaupan häiriintyminen vaikuttaa sianlihan tuotantoon, vientiin, tuontiin ja markkinahintoihin Suomessa kuukausitasolla. Vienti jaetaan EU-maihin ja EU:n ulkopuolisiin maihin kohdistuvaan vientiin, jolloin voidaan tarkastella EU:n ja muiden maiden reaktioiden vaikutuksia tautipurkauksen aiheuttamiin menetyksiin. Vientishokin kesto oletettiin stokastiseksi. Erilaisia vaihtoehtoja odotetun vientishokin kestosta tarkasteltiin.

Malli simuloi vientikysynnän muutoksista, eläintuotantokapasiteetin käyttöasteesta, lisääntyneestä uudistustarpeesta ja eläinten poistoista aiheutuvat kustannukset. Sekä tuotanto että kulutus voivat sopeutua taudinpurkauksen aiheuttamaan häiriöön, mutta tuotannon sopeutumista hidastaa lyhyt aikajänne, sillä emakoiden määrää ja siten lihantuotantoa voidaan lisätä vasta usean kuukauden tai jopa vuoden aikajänteellä. Lihan hinta on keskeinen tuotanto- ja kulutuspäätöksiin vaikuttava tekijä (Kuva 1).

Tasapainomallissa taudinpurkauksesta seuraa sianlihan viennin keskeytyminen. Tässä esitetyissä tuloksissa keskeytys kohdistuu lähinnä EU:n ulkopuoliseen vientiin. Vientihäiriön kestoksi oletettiin ensimmäisen tautihavainnon ja viimeisten rajoittavien määräysten poistamisen välinen aika lisättynä kolmella kuukaudella (+/- stokastisuus). Tämä skenaario perustui epidemiologisiin simulaatioihin ja eläintautijärjestö OIE:n suosituksiin. Vientihäiriön toteutuva kesto on ennalta tuntematon, mutta sen odotettu kesto tunnetaan. Se, että vientihäiriön kestoa ei tunneta etukäteen, voi aiheuttaa merkittäviä tappioita tuottajille. Häiriön vaikutusta tuloksiin tarkastellaan sekä häiriön odotetun keston että vientimarkkinoiden sulkeutumisasteen (koko vienti tai EU:n ulkopuolinen vienti keskeytyy) näkökulmasta.

Jokaisella hetkellä sikamarkkinoita voidaan kuvata kolmella tilamuuttujalla, jotka ovat tuotannossa olevien emakoiden lukumäärä, kasvatettavana olevien lihasikojen ja porsaiden lukumäärä sekä vientimarkkinoiden tilanne. Taudinpurkauksesta aiheutuvat menetykset laskettiin arvofunktion erotuksena tilanteista, jossa vienti on ja ei ole häiriintynyt, sillä viennin häiriintyminen on yhteydessä taudinpurkauksen esiintymiseen. Niemi ja Lehtonen (2010) ovat kuvanneet mallia yksityiskohtaisemmin. 


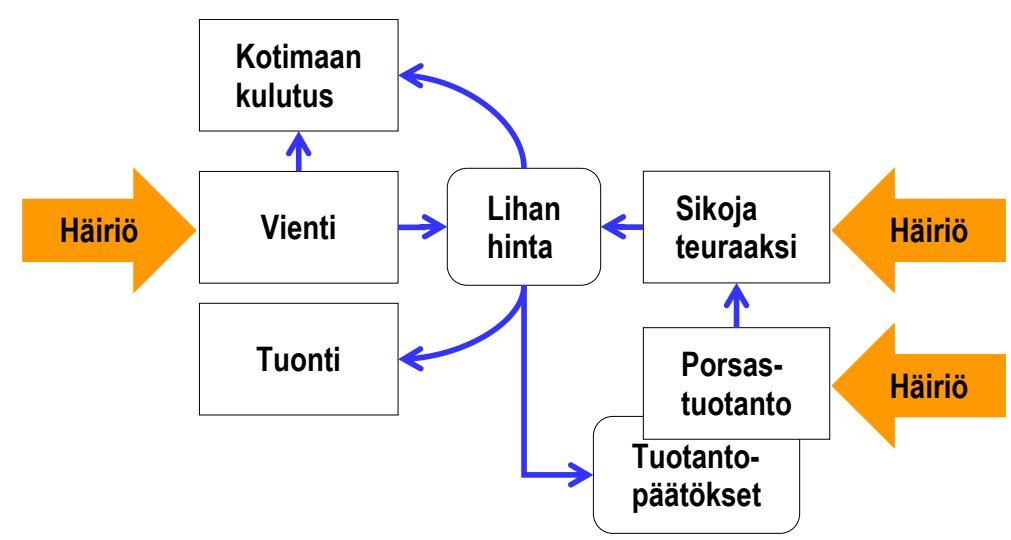

Kuva 1. Osittaisen tasapainon mallilla simuloidaan taudinpurkaukseen liittyvän vientihäiriön sekä taudin vuoksi markkinoilta poistuvien eläinten vaikutukset sianlihan hintaan, kysyntään ja tuotantopäätöksiin.

\section{Tulokset ja tulosten tarkastelu}

Afrikkalaisen sikaruton simuloitiin leviävän vähintään kahdelle tilalle 23 prosentissa simulaatioista. Tällöin epidemian keskimääräinen koko oli 2,6 tartunnan saanutta tilaa $(\mathrm{CV}=0.46)$. Tartunnan saaneiden tilojen lukumäärä vaikutti siihen, miten monta sikatilaa sijaitsi suoja- ja valvontavyöhykkeillä. Yhtä tartunnan saanutta tilaa kohti keskimäärin kolme muuta tilaa jäi suojavyöhykkeelle ja 14 tilaa valvontavyöhykkeelle. Epideemisessä taudinpurkauksessa tartunnan saaneilla tiloilla oli keskimäärin 1780 sikaa, suojavyöhykkeiden tiloilla keskimäärin 4448 sikaa ja valvontavyöhykkeillä sijaitsevilla tiloilla keskimäärin 20546 sikaa. Ensimmäisen tartunnan saaneen tilan sijainti vaikutti vain vähän tartunnan saaneiden tilojen lukumäärään. Suurimpia tautipurkaukset olivat, kun ne alkoivat Vaasan, Turun tai Kuopion läänineläinlääkärialueilta.

Verovaroista korvattavat välittömät kustannukset olivat useimmissa tapauksissa alle miljoona euroa (keskiarvo 0.4 miljoonaa euroa, $95 \%$ simulaatioista välillä 0.1-1.0 miljoonaa euroa), sillä taudin arvioitiin leviävän useimmiten vain 1-2 sikatilalle. Tartunnan saaneen tilan suuri koko, porsastuotanto ja sopiva sijainti lisäsivät tappioita.

Pääasiallinen ja selvästi suurin syy taloudellisiin menetyksiin oli sianlihan viennin häiriintymisestä seurannut vientitulojen menetys ja kotimaan lihamarkkinoiden myllerrys. Taudin esiintyminen Suomessa keskeyttänee sianlihan viennin EU:n ulkopuolisiin maihin, ja jossain määrin EU:n alueelle. Kotimaan markkinoille syntyy ylitarjontaa, joka laskee sianlihan hintaa. Nämä menetykset kohdistuivat sianlihan tuottajiin.

Sika-alan tappioiksi simuloitiin 7,4-38,1 miljoonaa euroa (95 \% simulaatioista, keskimäärin 17,3 miljoonaa euroa; Kuva 2), kun vienti EU:n ulkopuolelle keskeytyi OIE:n ohjeiden mukaan. yhteiskunnan kokonaistappio oli tätä pienempi (4,6-22,7 miljoonaa euroa, keskimäärin 10.5 miljoonaa euroa), sillä kuluttajat hyötyivät ylitarjonnasta. Sikatilaa kohti laskettuna tappiot olivat siis noin 7400 euroa, ja yksittäistä kuluttajaa kohti saatu hyöty keskimäärin 1-1,5 euroa (Kuva 3).

Tartuntatila ja rajoittavat määräykset saaneet tilat kärsivät myös tuotannonkeskeytyksistä ja -häiriöistä. Niiden kustannukset sisältyvät tuottajien tappioihin. Nämä menetykset olivat kuitenkin melko pieniä verrattuna viennin häiriintymisestä aiheutuneisiin menetyksiin.

Vientihäiriön pidentyminen nostaa tuottajien tappioita. Koska vientihäiriön kestoa ei tiedetä etukäteen, mallinnettiin sen kesto stokastisena muuttujana. Kuva 3 havainnollistaa, miten vientihäiriön odotetun keston pitkittyminen nostaa tuottajien menetyksiä. Lisäksi kuva 3 havainnollistaa, miten tappioiden suuruuteen liittyvä epävarmuus lisääntyy vientihäiriön keston pitkittyessä.

Afrikkalaisen sikaruton aiheuttamat taloudelliset tappiot vaihtelivat jonkin verran tartuntatilan tyypin mukaan. Taudinpurkaukset, joissa ensimmäisenä Suomessa tartunnan saanut tila oli porsastuotantosikala, aiheuttivat keskimäärin noin 0,3 miljoonaa euroa suuremmat tappiot kuin yhdistelmäsikalan ollessa ensimmäinen tartunnan saanut tila. Porsastuotantotilojen aiheuttamat taudinpurkaukset olivat noin 0,6 miljoonaa euroa kalliimpia kuin lihasikalasta alkaneet taudinpurkaukset. Myös ensimmäisenä tartunnan saaneen tilan sijainnilla oli merkitystä. Itä- tai Pohjois-Suomesta joiltain alueilta alkaneet taudinpurkaukset aiheuttivat jopa 0,5-1,5 miljoonaa euroa pienemmät tappiot kuin sikatuotannon pääalueilta alkaneet taudinpurkaukset. 
Vuoden 2009 tilanteen lisäksi tutkimuksessa arvioitiin, miten afrikkalaisen sikaruton kustannusten riskit voisivat muuttua tulevaisuudessa. Vuoden 2033 arvioidulla tilakoolla ja tilamäärällä simuloitaessa afrikkalaisen sikaruton taudinpurkauksen yhteiskunnalle aiheuttamiksi kokonaismenetyksiksi arvioitiin 10,711,3 miljoonaa euroa riippuen siitä, miten suuri osuus eläinliikennekontakteista reititettiin uudestaan (Kuva 4). Pienimmät tappiot simuloitiin tapauksessa, jossa jatkavien tilojen eläinkontaktimäärä nousi vähän vaikka niiden koon oletettiin kasvavan huomattavasti. Mikäli kaikki lopettaneiden tilojen kontaktit reititettiin uudelleen jatkaville tiloille, olivat simuloidut tappiot 95 prosentissa tapauksista 5-25 miljoonaa euroa. Tulevaisuusskenaariossa voimakkaimmin kasvoivat tartuntatilan puhdistuksesta, desinfektiosta, ja eläinten lopetuksesta ym. aiheutuneet suorat kustannukset. Kontaktien linkitysaste vaikutti kuitenkin vain melko vähän taudinpurkauksen kokonaiskustannuksiin.

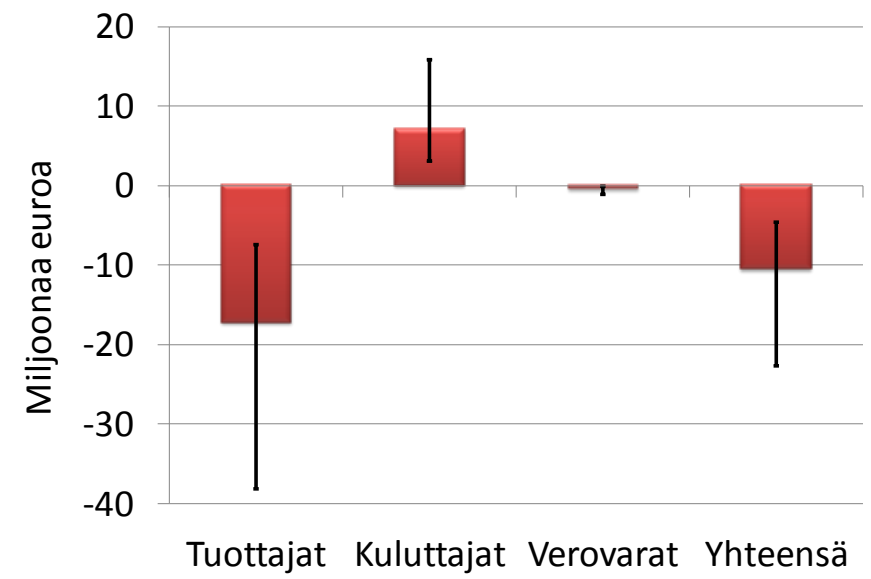

Kuva 2. Afrikkalaisen sikaruton taloudelliset vaikutukset (keskiarvo ja $95 \%$ vaihteluväli), kun vienti EU:n ulkopuolisiin maihin keskeytyy OIE:n ohjeen mukaisesti.

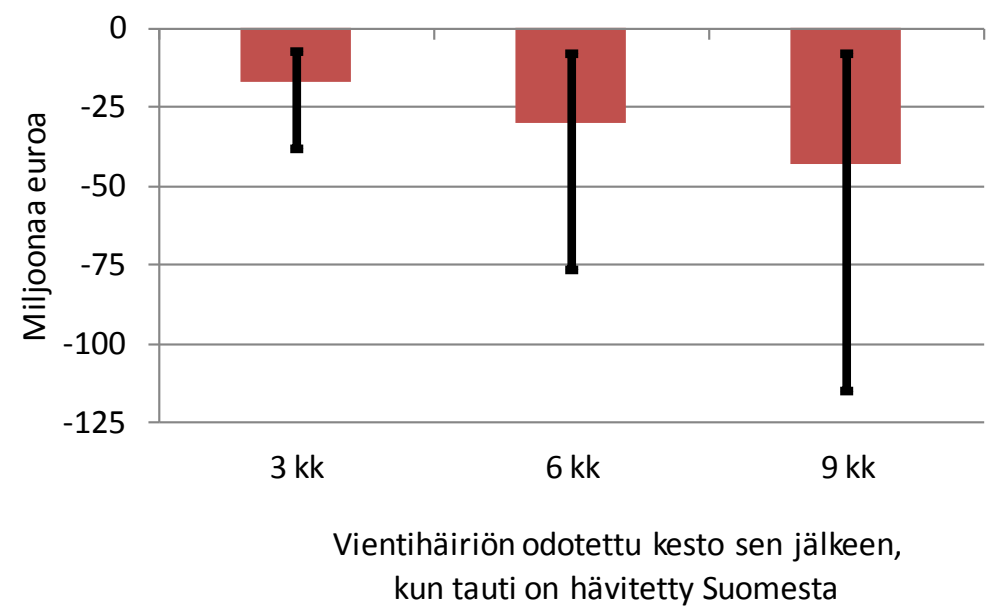

Kuva 3. EU:n ulkopuolisen viennin häiriintymisen keston vaikutus tuottajille (sikatilat ja lihateollisuus, keskimäärin sekä vaihteluväli, jonne sijoittuu $95 \%$ simulaatioista). Häiriön odotettu kesto on kuukausina (keskimäärin) sen jälkeen, kun tauti on hävitetty Suomesta. 


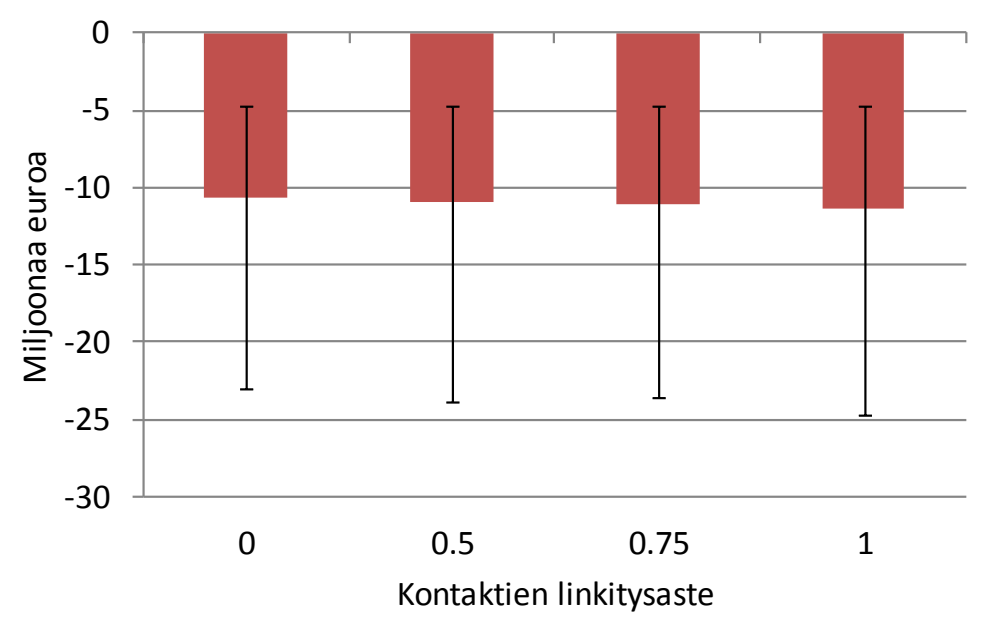

Kuva 4. Afrikkalaisen sikaruton taloudelliset vaikutukset (keskiarvo ja $95 \%$ vaihteluväli) yhteiskunnalle vuoteen 2033 ajoittuvassa projektiossa ja sen mukaan, miten suuri osuus (0-100\%) lopettavien tilojen kontakteista linkittyi uudelleen jatkaville tiloille.

\section{Johtopäätökset}

Afrikkalainen sikarutto voisi Suomeen levitessään aiheuttaa merkittäviä tappioita sika-alalle. Suurimmat taloudelliset tappiot, 7,4-38,1 miljoonaa euroa, arvioitiin aiheutuvan kotieläinyrityksille. Koko kansantalouden tappiot jäivät tuottajien tappioita pienemmiksi, sillä taudin simuloitiin aiheuttavan tyypillisesti 4,6-22,7 miljoonan euron tappiot.

Pääosa tappioista johtuu sianlihan viennin häiriintymisestä. Taudin esiintyminen Suomessa keskeyttänee sikatuotteiden viennin EU:n ulkopuolisiin maihin, ja jossain määrin myös EU:n alueelle. Siten kotimaan markkinoille syntyy ylitarjontaa, joka laskee sianlihan hintaa Suomessa. Simulaatiotulosten perusteella kuluttajien arvioitiin hyötyvän hetkellisestä ylitarjonnasta. Vientireaktioiden voimakkuus, kesto ja ponnistelut viennin uudelleen avaamiseksi ovatkin sikatuotannon näkökulmasta erittäin tärkeitä tekijöitä. Lisäksi taudin hävittäminen ja leviämisen ennaltaehkäisy aiheuttavat kustannuksia.

Tappiot kasvoivat, jos tartunnan saanut tila oli suuri, harjoitti porsastuotantoa tai sijaitsi alueella, jossa on paljon sikoja. Tappiot eivät kuitenkaan näyttäisi kasvavan voimakkaasti sikatalouden rakennekehityksen myötä.

\section{Kirjallisuus}

European council. 2002. Council Directive 2002/60/EC of 27 June 2002 laying down specific provisions for the control of African swine fever and amending Directive 92/119/EEC as regards Teschen disease and African swine fever (Text with EEA relevance)

Euroopan komissio. 2015. African swine fever. http://ec.europa.eu/food/animal/diseases/controlmeasures/asf_en.htm Lyytikäinen, T., Niemi, J.K., Sahlström, L., Virtanen, T., Rintakoski, S., Kyyrö, J., Sinisalo, A., Lehtonen, H. 2015. The effects of structural change in agriculture on the spread of animal disease in Finland. Evira Research Reports 3/2015. http://www.evira.fi/portal/en/about+evira/publications/?a=view\&productId=424

MMMa 10/2014. Maa- ja metsätalousministeriön asetus afrikkalaisen sikaruton vastustamisesta (6/EEO/2003). Dnro $527 / 14 / 2014$.

Niemi, J.K. \& Lehtonen, H. 2011. Modelling pig sector dynamic adjustment to livestock epidemics with stochasticduration trade disruptions. European Review of Agricultural Economics 38: 529-551

Nigsch A., Costard S, Jones B.A., Pfeiffer D.U. \& Wieland B. 2013. Stochastic spatio-temporal modelling of African swine fever spread in the European Union during the high risk period. Preventive Veterinary Medicine 108, 262-275.

OIE. 2007. Terrestrial animal health code. 2007. Office International des Epizooties, Paris.

OIE 2015. Summary of Immediate notifications and Follow-ups 2015, African swine fever.

http://www.oie.int/wahis_2/public/wahid.php/Diseaseinformation/Immsummary

Oravainen, J., Sahlström, L., Lyytikäinen, T. 2011. Possible routes of entry into the country for African swine fever Risk profile. Evira Research Reports 5/2011. 
Raulo S. \&Lyytikäinen T. 2005. Epidemic outbreak of classical swine fever in Finland, quantitative risk assessment (In Finnish). National Veterinary and Food Research Institute EELA Publications. 06/2005. 192 p.

Stegeman J.A., Elbers A.R.W., Bouma A, de Jong M.C.M . 2002. Rate of inter-herd transmission of CSF virus by different types of contact during the 1997-8 epidemic in The Netherlands. Epidemiology and Infection 128, $285-291$.

Tämä kirjoitus perustuu MMM:n rahoittaman ja Eviran ja Luonnonvarakeskuksen toteuttamaan tutkimukseen. Lisätietoja saatavilla julkaisusta Lyytikäinen ym. (2015). 